\title{
Pemanfaatan Kearifan Lokal Maluku dalam Pengembangan Bahan Ajar Menulis Teks Prosedur untuk Siswa Kelas VII
}

\author{
Dince Avia Kormasela ${ }^{1}$, Dawud ${ }^{1}$, AH. Rofi'uddin ${ }^{1}$ \\ ${ }^{1}$ Pendidikan Bahasa Indonesia-Universitas Negeri Malang
}

\begin{tabular}{l}
\hline \hline INFO ARTIKEL \\
\hline Riwayat Artikel: \\
Diterima: 03-01-2020 \\
Disetujui: 10-08-2020 \\
\hline
\end{tabular}

\section{Kata kunci:}

Maluku local wisdom; teaching materials; procedure text; kearifan lokal Maluku; bahan ajar; teks prosedur

\begin{tabular}{l} 
ABSTRAK \\
\hline Abstract: Teaching materials are a very important learning tool to support learning \\
activities and are arranged systematically so that they can be used in teaching and \\
learning activities. Basically, instructional materials compiled include knowledge and \\
skills and contain information, facts, concepts and learning objectives. The teaching \\
material developed in this study was writing a text for procedures containing Maluku \\
local wisdom. Teaching materials that have been prepared display a variety of Maluku \\
local wisdom formed in the procedural text of each unit. Text that contain step or steps \\
that must be done to get the final destination is known as the procedure text. \\
Abstrak: Bahan ajar adalah sebuah alat pembelajaran yang sangat penting untuk \\
menunjang kegiatan pembelajaran dan disusun dengan sistematis sehingga dapat \\
dipergunakan pada kegiatan belajar mengajar. Pada dasarnya, bahan disusun mencakup \\
pengetahuan maupun keterampilan dan berisi informasi, fakta, konsep, dan tujuan \\
pembelajaran. Bahan ajar yang dikembangkan dalam penelitian ini adalah menulis teks \\
prosedur bermuatan kearifan lokal Maluku. Bahan ajar yang telah disusun menampilkan \\
beragam kearifan lokal Maluku yang dibentuk dalam teks prosedur pada setiap unit. \\
Teks yang berisi tahapan atau langkah yang wajib dilakukan guna mendapatkan tujuan \\
akhir dikenal dengan nama teks prosedur.
\end{tabular}

\author{
Alamat Korespondensi: \\ Dince Avia Kormasela \\ Pendidikan Bahasa Indonesia \\ Universitas Negeri Malang \\ Jalan Semarang 5 Malang \\ E-mail: dinceavia@gmail.com
}

Bahan ajar mempunyai peran yang sangat penting bagi aktivitas belajar mengajar. Bahan ajar yang telah disusun dengan baik memiliki fungsi penting untuk seorang guru demi meningkatkan proses pembelajaran yang lebih efektif dan efisien (Pratama, Pratiwi, \& Andajani, 2016). Selain itu, bahan ajar yang disusun selain berisi pengetahuan, terdapat juga keterampilan yang membantu siswa dalam kegiatan belajar mengajar guna tercapainya kompetensi dalam kurikulum. Bahan ajar yang lebih dikenal dengan materi pembelajaran (instruksional materials) umumnya berisi keterampilan, pengetahuan, dan sikap yang harus diajarkan kepada siswa untuk memenuhi standar kompetensi yang telah ditentukan (Saputro, Widodo, Rusminto, 2014). Bahan ajar yang dipakai bukan hanya menolong guru dalam belajar dan mengajar, tetapi dapat membantu peserta didik. Bahan ajar juga dipahami sebagai sebuah sarana praktis karena materi yang disajikan pada bahan ajar berbentuk unit-unit. Bahan ajar dipakai sebagai alat, teks, maupun berita yang dibutuhkan guru guna merencanakan serta menelaah penerapan dalam pembelajaran (Dewi, Hudiyono, \& Mulawarman, 2018). Selain kegiatan, peranan seorang guru, keberhasilan para siswa juga dipengaruhi oleh bahan ajar. Oleh karena itu, sangat penting untuk merumuskan bahan ajar yang dapat mendukung berjalannya pendidikan yang baik (Wijayanti \& Zulaeha, 2015). Dengan demikian, bahan ajar atau materi ajar yang disusun harus disesuaikan dengan kurikulum yang sedang dipakai atau berlaku, agar bahan ajar tersebut dapat bermanfaat bagi kepentingan kegiatan belajar mengajar guna ketercapaian kompetensi pada kurikulum.

Salah satu pembelajaran yang sangat penting untuk diajarkan kepada siswa sejak dini adalah pembelajaran menulis. Dikatakan demikian karena menulis adalah salah satu keterampilan berbahasa yang produktif karena menulis merupakan tindakan untuk menciptakan sesuatu sehingga tidak dapat dicapai hanya dalam sekali menulis. Menulis adalah ekspresi individu seperti membaca untuk pemahaman (Durukan, 2011). Menulis diartikan sebagai sebuah aktivitas yang berhubungan dengan bernalar (Wikanengsih, 2013). Wikanengsih menambahkan bahwa wujud dari kegiatan berpikir yang berpengaruh pada kegiatan bertindak adalah menggunakan bahasa saat menulis. Selain itu, menulis masuk dalam kategori keterampilan berbahasa yang sangat sulit. Keterampilan menulis didapatkan tidak melalui cara yang instan, namun melewati proses untuk membentuk pola-pola gagasan yang utuh dan tepat. Keterampilan menulis dihasilkan lewat proses belajar dan berlatih (Sarjono Owon, 
2017). Pada aktivitas menulis, seorang penulis harus cekatan dalam menggunakan struktur bahasa dan kata. Tahap ini adalah sebuah jenjang yang begitu rumit karena bukan hanya menuangkan ide, namun seseorang dituntut untuk meluapkan gagasan, kemauan, dan perasaan bahkan impian orang lain yang dituangkan dalam tulisan (Qalby, 2017). Menjadi seorang penulis yang profesional membutuhkan latihan dengan berulang serta membutuhkan waktu yang relatif panjang. Keterampilan menulis itu sendiri adalah sebuah proses perkembangan melalui banyak latihan (Oktaria, Andayani, \& Saddhono, 2017). Mereka menambahkan bahwa agar memperoleh keterampilan menulis, tidak cukup jika hanya belajar tentang pengetahuan yang berkaitan dengan teori menulis saja apalagi cuma mengingat dan mengucapkan makna dari setiap istilah yang ada pada kegiatan karang mengarang. Ketika menulis, penulis harus mengidentifikasi terlebih dahulu pembaca tulisannya sehingga penulis mampu menggunakan mengomunikasikan idenya dengan bahasa yang tepat (Astuti \& Mustadi, 2014).

Pada pembelajaran menulis, siswa akan menggunakan tulisan yang dibuatnya sebagai landasan berpikir agar dapat berkembang dalam menulis. Dalam menulis, siswa akan mengawali dari menulis hal-hal yang sederhana untuk melatih kemampuan menulisnya. Siswa akan memulai dari menentukan judul, menyusun kerangka hingga pengembangan kalimat menjadi paragraf. Para siswa terlebih dahulu belajar cara menulis kalimat sederhana dan kompleks, dan kemudian mulai membuat paragraf dari model, bingkai, dan panduan lainnya (Rao, 2007). Kemajuan penggunaan tulisan sebagai cara berpikir, serta produksi bahasa, muncul hanya setelah satu dekade atau lebih pengalaman menulis (Kellogg \& Raulerson, 2007). Dalam keterampilan menulis, seseorang harus dapat mentransfer pengetahuannya ke dalam bentuk tulis dengan baik sehingga dapat menarik minat pembaca. Pada tahap transformasi pengetahuan cukup terperinci dan cukup stabil untuk dipertahankan dalam memori kerja untuk memungkinkan interaksi antara penulis dan representasi teks (Kellogg, 2008). Dengan demikian, terampil dalam menulis bukan hal yang mudah untuk dicapai, namun melalui proses yang panjang dan bertahap melalui latihan merangkai gagasan, konsep maupun perasaan yang menjadi sebuah tulisan yang utuh dan sempurna, serta mampu untuk mengidentifikasi kebutuhan pembaca.

Mata pelajaran bahasa Indonesia yang terdapat dalam kurikulum 2013 berisikan sebuah kegiatan belajar mengajar yang berorientasi kepada teks. Oleh karena itu, siswa harus mampu untuk memproduksi teks dengan baik, bukan hanya sebatas pengetahuan berbahasa saja. Pembelajaran berbasis teks tidak hanya sebatas pengetahuan berbahasa, tetapi teks mempunyai kegunaan demi sebagai asal aktualisasi dari pemakainya dalam ranah sosial serta budaya pendidikan (Anggraini, Rusminto, Nurlaksana, Agustina, 2015). Ada beberapa teks yang diajarkan di kelas VII, salah satu adalah teks prosedur. Teks prosedur adalah sebuah teks yang sangat penting bagi pemenuhan kebutuhan masyarakat. Dikatakan demikian karena teks prosedur adalah sebuah teks yang didalamnya terdapat langkah-langkah atau cara-cara dalam melakukan sesuatu. Dengan adanya teks prosedur, seseorang akan sangat terbantu dan pekerjaan yang dilakukan akan semakin mudah. Teks yang menjelaskan langkah atau tahapan dengan jelas, lengkap dan rinci terkait bagaimana jalannya untuk mengerjakan sesuatu (Lestari, Herdiantina, Sudrajat, 2018). Oleh karena itu, teks prosedur sangat tepat dipelajari siswa sebab sering kali siswa mengalaminya dalam kehidupan sehari-hari. Teks prosedur yang disusun memiliki struktur teks yang agak berbeda dari teks lain. Teks prosedur juga diatur dengan struktur teks, tujuan dan langkah-langkah (Kristanti, Sriasih, Astika, 2015).

Kearifan lokal begitu penting untuk dimasukkan pada bidang pendidikan. Kearifan lokal yang masih bersifat tradisional tidak dapat bertahan dalam jeramnya arus modernisasi saat ini dan dapat berubah mengikuti perkembangan zaman. Kearifan lokal adalah pengetahuan pokok yang didapat dari keseimbangan hidup dengan alam (Mungmachon, 2012). Kearifan lokal secara substansial merupakan nilai, norma, dan harga yang berjalan dalam suatu masyarakat. Kearifan lokal dapat pula dijadikan sebagai simbol serta interaksi simbolik yang lahir dari hubungan antara seorang dengan yang kain, kemudian menjadi begitu penting sebagai tanda dari tanggapan yang saling dekat dengan unsur-unsur kearifan lokal (Meliono, 2011). Dalam kearifan lokal tersimpan norma bahkan nilai-nilai sosial yang menata bagaimana mestinya daya dukung lingkungan alam dengan gaya hidup serta kebutuhan manusia menjadi imbang yang dibangun terkandung dalam kearifan lokal (Pattinama, 2009). Kearifan lokal setiap darah kaya akan nilai-nilai yang dipercaya dapat digunakan sebagai pedoman hidup. Nilai-nilai sosial yang dipikul dalam strata sosial masyarakat itu sendiri dibangun dalam kearifan lokal, dan dijadikan sebagai petunjuk, pengendali, bahkan tanda-tanda untuk bertindak dalam berbagai dimensi kehidupan masyarakat baik pada saat membangun hubungan dengan sesama manusia maupun dengan alam (Asriati, 2012). Kearifan lokal juga dipahami sebagai petunjuk hidup bahkan ilmu pengetahuan serta berbagai rencana hidup yang ada pada wujud aktivitas yang dijalankan oleh penduduk lokal guna menjawab berbagai persoalan untuk memenuhi keperluan mereka (Fajarini, 2014).

Kearifan lokal biasanya menata bermacam-macam aspek kehidupan masyarakat seperti hubungan sosial antar masyarakat, ritual peribadahan, kepercayaan, mitos-mitos bahkan sampai hukum yang berkaitan dengan adat (Persada, Mangunjaya, Tobing, 2018). Nilai-nilai kearifan lokal dapat melindungi kehidupan masyarakat Indonesia yang baik di era globalisasi dan informasi saat (Sugiyo \& Purwastuti, 2017). Kearifan lokal tidak hanya sebatas itu, tetapi juga tentang cara bertahan hidup masyarakat setempat, mulai dari kuliner, mata pencaharian bahkan tradisi lain yang telah ada sejak dulu, serta diwariskan dari generasi ke generasi. Kearifan lokal tidak hanya sebatas tradisi turun temurun yang harus dilestarikan oleh generasi penerus, tetapi berkaitan dengan ilmu pengetahuan serta cara mendapatkan dan mempertahankan. Kearifan lokal berkaitan dengan cara pengetahuan dihasilkan, kemudian disimpan, diterapkan, dikelola, dan akhirnya dijadikan sebagai 
warisan (Selasih \& Sudarsana, 2018). Bahan ajar ini dikembangkan bermuatan kearifan lokal. Alasan pemanfaatan kearifan lokal sebagai tema dalam bahan ajar ini guna membantu memudahkan siswa untuk memahami materi teks prosedur. Penyajian materi dalam bahan ajar sesuai dengan kondisi, lingkungan, serta contoh konkret yang dialami oleh siswa. Di samping itu, pemanfaatan kearifan lokal dalam bahan ajar dapat membantu memperkenalkan budaya kepada siswa lewat pembelajaran sehingga kearifan lokal setempat dapat dilestarikan sebagai pedoman hidup secara turun temurun. Selain itu, tema kearifan lokal dipakai dalam pengembangan bahan ajar karena sesuai dengan tingkat berpikir siswa kelas VII.

Pemanfaatan kearifan lokal dalam bahan ajar karena kearifan lokal memiliki posisi yang sangat penting dalam dunia pendidikan. Kearifan lokal penting untuk tetap dekat lingkungan sekolah dan berinteraksi dengan peserta didik (Pornpimon, Wallapha, \& Prayuth, 2014). Pendidikan yang berbasis kearifan lokal memiliki kaitan yang kuat dalam mengembangkan kecakapan hidup yang berpusat pada potensi lokal daerah (Nadlir, 2016). Pemilihan dan pemanfaatan kearifan lokal atau budaya lokal dalam bahan ajar menulis teks prosedur juga sebagai sarana mengembangkan karakter siswa. Hal ini dilakukan untuk pemenuhan pendidikan karakter dalam pembelajaran sesuai dengan yang ditetapkan dalam kurikulum. Pendidikan karakter tidak dapat dipisahkan dari bentuk pendidikan yang sifatnya kognitif atau akademik (Suyitno, 2013). Suyitno menambahkan bahwa konsep pendidikan tersebut mesti diintegrasikan dalam kurikulum. Dengan demikian, pemanfaatan kearifan lokal Maluku layak digunakan dalam pengembangan bahan ajar menulis teks prosedur.

Bahan ajar ini dikembangkan sesuai dengan kebutuhan siswa. Pembelajaran teks prosedur juga terdapat dalam kurikulum 2013 tingkat SMP khususnya kelas VII. Kemampuan siswa dalam memahami materi teks prosedur yang tidak memadai menjadi pendorong dan motivasi untuk mengembangkan bahan ajar dengan memanfaatkan kearifan lokal Maluku. Di samping itu, kurangnya sumber belajar tentang materi teks prosedur menjadikan bahan ajar ini sebagai suplemen pelengkap buku induk dalam pembelajaran teks prosedur.

Penelitian pengembangan ini memiliki enam tujuan. Tujuan-tujuan tersebut, yaitu (1) menghasilkan bahan ajar mengenal teks prosedur, (2) menghasilkan bahan ajar menjelaskan alat dan bahan dalam menulis teks prosedur, (3) menghasilkan bahan ajar memahami langkah-langkah dalam mengerjakan sesuatu, (4) menghasilkan bahan ajar memahami struktur teks prosedur, (5) menghasilkan bahan ajar mengidentifikasi kaidah kebahasaan dan langkah-langkah dalam menyusun teks prosedur, dan (6) menghasilkan bahan ajar menulis teks prosedur.

\section{METODE}

Penelitian pengembangan ini menggunakan teknik analisis data secara kualitatif dan teknik analisis data secara kuantitatif. Analisis data secara kualitatif digunakan untuk menganalisis data verbal yang didapat pada saat wawancara dan catatan tertulis berupa saran, masukan, maupun komentar yang didapat dalam angket pada saat uji kelayakan. Langkah yang ditempuh untuk melakukan analisis kualitatif meliputi empat langkah, yakni (1) mengumpulkan data verbal tertulis dari angket uji serta data lisan hasil wawancara terhadap ahli dan praktisi saat uji kelayakan, (2) mentranskrip data verbal lisan yang didapat pada saat wawancara ahli dan praktisi pada uji kelayakan, (3) mengelompokan data verbal tulis dan hasil transkrip verbal lisan ke dalam kelompok kriteria yang sesuai, dan (4) menganalisis data dan merumuskan simpulan berdasarkan kelompok data sebagai dasar untuk tindak lanjut terhadap produk bahan ajar yang dikembangkan. Analisis data kuantitatif digunakan untuk menganalisis data yang berwujud angka-angka. Data numerik tersebut berupa skor yang didapat dari angket uji kelayakan oleh ahli dan praktisi maupun nilai pretes dan postes dari uji coba lapangan. Teknik analisis kuantitatif terdiri dari dua tahap, yakni (1) skor yang didapat dari ahli dan praktisi dibuat dalam bentuk persentase, (2) nilai prestes dan postes yang didapat dari siswa dianalisis menggunakan teknik uji-t (paried sample t-test).

Sumber data dalam penelitian pengembangan ini terdiri dari dua sumber, yaitu (1) sumber aktif dan (2) sumber pasif. Sumber data aktif terdiri dari ahli bahan ajar dan ahli materi dan Bahasa, guru mata pelajaran Bahasa Indonesia, dan siswa kelas VII-1 SMP Negeri 13 Ambon. Sumber data pasif berupa tulisan siswa kelas VII-1 SMP Negeri 13 Ambon yang merupakan hasil menulis teks prosedur, yakni pretes dan postes. Instrumen yang dipakai pada penelitian ini adalah wawancara, observasi, dan angket. Wawancara dipakai pada tahap pengumpulan informasi awal guna mendapatkan informasi tentang kebutuhan di lapangan. Observasi dipakai sebagai panduan untuk mengamati dan mencatat proses pembelajaran di kelas. Angket digunakan untuk mengumpulkan data dari ahli dan praktisi. Data yang terdapat dalam penelitian pengembangan ini berupa data kuantitatif dan data kualitatif. Data kuantitatif berupa skor yang diperoleh dari angket saat uji kelayakan. Data kualitatif berupa kata-kata, meliputi catatan hasil wawancara saat studi pendahuluan, komentar, saran, atau masukan dari ahli dan praktisi saat uji kelayakan.

Penelitian pengembangan bahan ajar ini menggunakan model Research \& Development $(R \& D)$. Model penelitian pengembangan Research and Depelopment (R\&D) terdiri dari sepuluh tahap (Sugiyono, 2016). Sepuluh tahap tersebut kemudian diadaptasikan menjadi delapan tahap sesuai dengan kebutuhan. Delapan tahap tersebut, meliputi (1) pengumpulan informasi awal, (2) perencanaan, (3) pengembangan produk, (4) uji kelayakan, (5) revisi produk awal, (6) uji coba lapangan, (7) penyempurnaan produk akhir, dan (8) produksi massal. Alasan diadaptasikan menjadi delapan tahap dikarenakan uji coba 
pemakaian pada tahap delapan telah digabungkan pada tahap enam, revisi produk yang terdapat pada tahap sembilan telah digabungkan pada tahap tujuh sehingga dari sepuluh tahap menjadi delapan tahap.

Pertama, pengumpulan informasi awal, tahap ini terdiri dari tiga kegiatan yaitu analisis kurikulum, telaah teori, dan studi lapangan. Analisis kurikulum dilakukan guna melihat materi-materi yang dibahas dalam mata pelajaran Bahasa Indonesia khususnya materi teks prosedur. Telaah teori dilakukan untuk melihat kebenaran teori yang digunakan dalam pengembangan produk. Teori-teori tersebut yaitu terori tentang bahan ajar, teori menulis, dan teori teks prosedur. Studi lapangan dilaksanakan dengan wawancara guru mata pelajaran bahasa Indonesia guna mengetahui kebutuhan siswa serta mengetahui tingkat kerumitan siswa dalam proses pembelajaran. Wawancara tersebut bertujuan untuk mengetahui fakta empiris yang ada di lapangan digunakan sebagai dasar dalam pengembangan produk.

Kedua, perencanaan, tahap ini terdiri dari tiga kegiatan, yaitu penetapan spesifikasi bahan ajar, perumusan indikator, dan pemilihan bahan (teks) yang sesuai dengan tema kearifan lokal Maluku. Penetapan spesifikasi bahan ajar dilakukan berdasarkan kebutuhan di lapangan. Perumusan indikator dilakukan sesuai spesifikasi bahan ajar yang telah ditetapkan karena spesifikasi bahan ajar tersebut yang dimasukkan ke dalam unit-unit bahan ajar. Pemilihan teks dilakukan berdasarkan tema yang telah ditetapkan, yaitu kearifan lokal Maluku.

Ketiga, pengembangan produk adalah tahap penyusunan bahan ajar. Kegiatan menyusun bahan ajar dilakukan berdasarkan spesifikasi bahan ajar yang telah ditetapkan serta indikator-indikator yang telah dirumuskan. Pada kegiatan pengembangan produk, spesifikasi bahan ajar tersebut dimasukkan menjadi unit-unit dalam bahan ajar, sedangkan indikatorindikator yang telah dirumuskan menjadi sub unit dalam bahan ajar hingga membentuk sebuah produk bahan ajar yang utuh. Pengembangan produk dalam penelitian ini adalah bahan ajar menulis teks prosedur bermuatan kearifan lokal Maluku. Pengembangan bahan ajar ini disesuaikan pada kebutuhan yang ada di lapangan.

Keempat, uji kelayakan dilaksanakan dengan melibatkan dua orang ahli serta praktisi. Produk bahan ajar yang telah selesai dikembangkan diberikan kepada ahli untuk dilakukan penilaian. Selesai validasi ahli, dilanjutkan dengan validasi dari praktisi yaitu guru mata pelajaran bahasa Indonesia. Uji ahli dan praktisi dilakukan dengan tujuan untuk dapat memperbaiki bahan ajar dari segi kesesuaian, keakuratan, dan kedalaman materi. Data dari uji kelayakan produk dipaparkan dalam bentuk data numerik dan data verbal. Data numerik dihitung dengan berlandaskan skor yang diperoleh dari angket, sedangkan data verbal berupa saran serta komentar secara lisan maupun tulisan yang diperoleh selama uji kelayakan produk. Skor yang didapat dalam angkat saat uji kelayakan diolah dan disajikan dalam bentuk persentase untuk setiap indikator.

Kelima, revisi produk dilakukan sesuai dengan pada saran dan komentar yang diberikan oleh ahli dan praktisi saat uji kelayakan. Dasar untuk melakukan perbaikan adalah saran maupun komentar yang didapat dari ahli dan praktisi. Produk yang telah selesai direvisi siap untuk diujicobakan kepada siswa. Tahap ini memaparkan hasil revisi produk berdasarkan komentar dan saran yang diberikan oleh ahli dan praktisi. Revisi tahap awal dilakukan ketika saran dan masukkan tentang perbaikan produk yang didapat dari ahli saat uji ahli dilakukan. Saran dan komentar dari uji ahli dilakukan sebelum bahan ajar Menulis Teks Prosedur Bermuatan Kearifan Lokal Maluku diujicobakan di lapangan.

Keenam, uji coba lapangan dilaksanakan di SMP Negeri 13 Ambon, dengan melibatkan siswa kelas VII-1 yang berjumlah siswa 25 orang. Uji coba lapangan ini akan menghasilkan uji keefektifan produk. Hasil uji keefektifan bahan ajar diketahui setelah kegiatan pretes dan postes dilaksanakan. Data uji lapangan yang adalah nilai pretes dan postes dianalisis melalui uji normalitas dan uji beda. Perolehan hasil analisis digunakan untuk menentukan kenormalan data pretes maupun postes serta perbedaan antara data pretes-postes. Hasil perhitungan antara normalitas data pretes-postes, diketahui hasil uji kolmogorov-smirnov data pretes adalah 0,064 dan data postes adalah 0,113 . Persebaran data dikatakan normal jika hasil pada uji normalitas lebih besar dari 0,05. Hasil perhitungan data pretes-postes lebih besar dari 0,05 maka data tersebut berdistribusi normal. Perhitungan data uji beda dalam penelitian ini menggunakan teknik uji-t (paried sample t-test). Penggunaan uji-t sampel berpasangan dalam analisis ini karena data yang dihasilkan ialah sepasang data yang memiliki subjek, yaitu skor hasil pretes dan postes. Hasil analisis uji-t adalah (1) diketahui mean pretes adalah 46, 56 sedangkan postes adalah 86,08, artinya terdapat selisih lebih antara pretes dan postes, (2) berdasarkan tabel tersebut, nilai pada hasil uji-t adalah -15,473, nilai signifikan adalah 0,000. Dengan demikian, ada perbedaan yang signifikan antara nilai pretes dan postes. Berdasarkan hasil uji-t terdapat nilai lebih antara nilai pretes dan postes sehingga dapat disimpulkan bahwa bahan ajar menulis teks prosedur bermuatan kearifan lokal Maluku sangat efektif sehingga layak untuk diimplementasikan.

Ketujuh, penyempurnaan produk akhir. Tahap ini dilakukan untuk memperbaiki bahan ajar yang telah diujicobakan kepada siswa. Penyempurnaan produk akhir dilakukan dengan tujuan untuk melengkapi kekurangan yang terdapat dalam bahan ajar. Penyempurnaan produk akhir selesai, produk dapat disebarluaskan sebagai suplemen pelengkap dalam pembelajaran.

Kedelapan, produk masal. Produk yang telah melewati penyempurnaan produk ahir setelah uji coba lapangan diproduksi sesuai dengan banyaknya permintaan dari pihak sekolah tempat pelaksanaan uji lapangan. Tahap ini peneliti telah memproduksi bahan ajar menulis teks prosedur bermuatan kearifan lokal Maluku sesuai dengan permintaan dari pihak sekolah tempat pelaksanaan uji coba lapangan. 


\section{HASIL}

Hasil penelitian pengembangan ini yaitu produk bahan ajar Menulis Teks Prosedur Bermuatan Kearifan Lokal Maluku untuk Siswa Kelas VII SMP. Produk yang dihasilkan berupa buku cetak. Produk ini terdiri dari enam unit, yakni (1) mengenal teks prosedur, (2) menjelaskan alat dan bahan dalam menulis teks prosedur, (3) memahami langkah-langkah dalam mengerjakan sesuatu, (4) memahami struktur teks prosedur, (5) mengidentifikasi kaidah kebahasaan dan langkah-langkah dalam menyusun teks prosedur, dan (6) menulis teks prosedur.

Pertama, mengenal teks prosedur terdiri dari enam sub unit. Keenam sub unit tersebut, meliputi (1) membaca dan memahami contoh teks prosedur, (2) merumuskan definisi teks prosedur, (3) menyimpulkan tujuan dan jenis teks prosedur, (4) menyimpulkan ciri teks prosedur, (5) menyimpulkan struktur teks prosedur, dan (6) menyimpulkan kaidah kebahasaan teks prosedur. Setiap sub unit dalam bagian ini dilengkapi dengan latihan-latihan yang berfungsi untuk merangsang pemahaman siswa dalam mengenal teks prosedur. Selain itu, dalam bagian ini dilengkapi dengan teori yang berkaitan dengan definisi teks prosedur, tujuan dan jenis teks prosedur, ciri teks prosedur, struktur teks prosedur, serta kaidah kebahasaan teks prosedur yang disajikan dalam ringkasan pada setiap sub unit.

Kedua, menjelaskan alat dan bahan dalam menulis teks prosedur terdiri dari dua sub unit, yakni (1) menjelaskan alat dalam menulis teks prosedur, dan (2) menjelaskan bahan dalam menulis teks prosedur. Pada bagian setiap sub unit dilengkapi dengan latihan yang digunakan untuk melatih siswa dalam mengenal alat dan bahan yang terdapat dalam teks prosedur. Pada sub unit pertama disajikan tiga buah gambar berbeda dan siswa diminta untuk menjelaskan alat yang terdapat dalam ketiga gambar tersebut. Pada sub unit kedua disajikan empat gambar berbeda, kemudian siswa diminta untuk menjelaskan bahan yang terdapat dalam keempat gambar tersebut, mulai dari nama bahan, spesifikasi bahan, ukuran bahan, serta cara khusus penggunaan bahan. Pada sub unit ini disajikan pula teori tentang alat dan bahan yang dimuat dalam ringkasan.

Ketiga, memahami langkah-langkah dalam mengerjakan sesuatu terdiri dari lima sub unit, yakni (1) memahami urutan kegiatan dalam teks prosedur, (2) memahami kalimat perintah dalam teks prosedur, (3) memahami kalimat larangan dalam teks prosedur, (4) memahami kalimat pertanyaan dalam teks prosedur, (6) memahami kalimat pernyataan dalam teks prosedur. Pada bagian ini, setiap sub unit dilengkapi dengan contoh-contoh yang digunakan sebagai dasar atau pedoman dalam menyelesaikan latihan yang disajikan. Latihan-latihan yang terdapat dalam setiap sub unit berfungsi untuk melatih siswa dalam memahami urutan kegiatan, kalimat perintah, kalimat larangan, kalimat pertanyaan, dan kalimat pernyataan yang terdapat dalam teks prosedur.

Keempat, memahami struktur teks prosedur terdiri dari empat sub unit, yakni (1) menganalisis judul yang terdapat dalam teks prosedur, (2) menganalisis tujuan yang terdapat dalam teks prosedur, (3) mengidentifikasi material yang terdapat dalam teks prosedur, dan (4) mengidentifikasi tahapan/langkah yang terdapat dalam teks prosedur. Pada bagian ini, materi yang disajikan dalam setiap sub unit diawali dengan penjelasan yang berkaitan dengan setiap sub unit, kemudian disajikan contohcontoh yang akan membantu siswa dalam menyelesaikan latihan yang diberikan. Latihan-latihan yang terdapat dalam bagian ini berfungsi untuk membatu siswa memahami struktur teks prosedur dengan benar dan tepat. Sub unit pertama latihan menganalisis judul yang terdapat dalam teks prosedur. Sub unit kedua latihan menganalisis tujuan yang terdapat dalam teks prosedur. Sub unit ketiga latihan mengidentifikasi material (alat dan bahan) yang terdapat dalam teks prosedur. Sub unit keempat latihan mengidentifikasi langkah/tahapan yang terdapat dalam teks prosedur.

Kelima, mengidentifikasi kaidah kebahasaan dan langkah-langkah dalam menyusun teks prosedur terdiri dari dua sub unit, yakni (1) mengidentifikasi kaidah kebahasaan dalam teks prosedur, dan (2) mengidentifikasi langkah-langkah dalam menyusun teks prosedur. Sub unit kedua terdiri dari tiga sub, yakni (1) menelaah teks prosedur secara utuh, (2) menyunting dan merevisi teks prosedur, dan (3) meringkas teks prosedur. Setiap sub dalam unit ini dilengkapi dengan contoh-contoh serta latihan-latihan yang berfungsi untuk melatih siswa mengidentifikasi kaidah kebahasaan teks prosedur, serta melatih menelaah teks prosedur, melatih menyunting dan merevisi, dan terakhir melatih meringkas teks prosedur.

Keenam, menulis teks prosedur terdiri dari lima sub unit, yakni (1) menentukan topik teks prosedur, (2) merumuskan judul teks prosedur, (3) menulis bagian pembuka teks prosedur, (4) menulis bagian inti teks prosedur, dan (5) menulis bagian penutup teks prosedur. Penyajian materi yang terdapat dalam sub unit pertama disajikan cara menentukan topik dalam menulis teks prosedur, kemudian diikuti dengan cara mengumpulkan informasi yang berkaitan dengan topik yang akan ditulis ke dalam teks prosedur. Pada sub unit kedua disajikan materi tentang cara merumuskan judul teks prosedur yang benar dan tepat. Pada bagian ini, setiap sub unit dilengkapi dengan latihan yang akan membantu siswa dalam menulis. Pada bagian ini siswa dilatih untuk menulis teks prosedur secara bertahap, seperti yang telah dijabarkan pada setiap sub unit.

\section{PEMBAHASAN \\ Mengenal Teks prosedur}

Unit satu dalam bahan ajar Menulis Teks Prosedur Bermuatan Kearifan Lokal Maluku untuk Sswa Klas VII SMP adalah mengenal teks prosedur. Unit ini terdiri dari dari enam sub unit, yakni (a) membaca dan memahami teks prosedur, (b) merumuskan definisi teks prosedur, (c) menyimpulkan tujuan dan jenis teks prosedur, (d) menyimpulkan ciri teks prosedur, (e) 
menyimpulkan struktur teks prosedur, (f) menyimpulkan kaidah kebahasaan teks prosedur. Pada bagian ini, setiap sub unit diawali dengan penyajian latihan. Latihan-latihan tersebut berfungsi untuk merangsang pemahaman dan tingkat berpikir siswa dalam mengenal teks prosedur guna menciptakan sebuah kegiatan pembelajaran yang aktif. Pada sub unit kedua, ketiga, kelima dan keenam, setelah latihan, disajikan teori tentang teks prosedur yang berkaitan dengan sub-sub unit tersebut yang dimuat dalam ringkasan pada setiap sub unit yang terdapat dalam unit satu.

Pada pengembangan produk awal, unit ini terdiri dari empat sub unit, yakni (a) pengertian teks prosedur, (b) tujuan dan jenis teks prosedur, (c) ciri teks prosedur, dan (d) struktur teks prosedur. Bentuk penyajian materi yang terdapat dalam bagian ini langsung pada teori tanpa disertai dengan latihan pada setiap sub unit. Melalui uji ahli, maka unit ini mengalami perubahan, baik dalam urutan unit maupun bentuk penyajian materi pada setiap sub unit. Penyajian materi dalam unit ini setelah revisi sangat berbeda dengan penyajian materi pada produk awal. Perubahan tersebut dilakukan sesuai dengan saran yang diberikan oleh ahli (V1). Berdasarkan saran dari ahli (V1), maka penyajian materi setelah revisi bersifat induktif, artinya penyajian materi dilakukan dari yang paling khusus menuju umum. Proses berpikir dari hal khusus menuju hal umum merupakan pembelajaran yang induktif (Aprilianti \& Sugiarto, 2014). Pembelajaran induktif diawali dengan menyajikan contoh-contoh, kemudian siswa dituntut membedakan, mengidentifikasi, menggeneralisasi, menginterpretasi, dan menyimpulkan (Sumaryati \& Sumarno, 2013). Di samping itu (Wanti, Juariah, Farlina, Kariadinata, \& Sugilar, 2017) menyatakan bahwa dalam pembelajaran induktif, siswa dituntut untuk aktif dalam proses belajar mengajar karena siswa harus dapat mengonstruksi pengetahuannya sendiri. Metode induktif dikembangkan pada premis bahwa stimulasi tambahan inisiatif siswa akan lebih meningkatkan pengalaman belajar (Jones, Holland, \& Oldmeadow, 2008). Dengan demikian, model pembelajaran yang bersifat induktif sangat ampuh untuk melatih siswa dalam berpikir secara kritis untuk dapat membedakan, menganalisis, mengonstruksikan, dan membuat simpulan dari apa yang dipelajari berdasarkan pemahaman dan pengetahuan yang dimiliki.

Penyajian teori dalam setiap sub unit pada produk awal terlalu banyak dan bahasa yang digunakan terlalu teoretis sehingga tidak cocok bagi siswa SMP kelas VII. Dengan demikian, berdasarkan saran dari (V2), revisi produk dilakukan dengan mengurangi teori pada setiap sub unit serta bahasa yang dipakai disederhanakan lagi sehingga sesuai dengan pemahaman dan tingkat berpikir siswa SMP kelas VII. Kearifan lokal Maluku yang terdapat dalam unit satu yaitu terdiri dari dua jenis. Pertama, kuliner khas Maluku salah satunya adalah cara membuat sagu woko komo-komo yang disajikan pada sub unit pertama. Kedua, alat musik daerah Maluku yaitu cara membuat tifa. Kuliner dan alat musik khas Maluku ini disajikan dalam unit satu dalam mengenal teks prosedur. Kearifan lokal Maluku yang dimasukkan dalam unit satu sangat jelas sehingga dapat membantu siswa dalam mengenal teks prosedur dengan baik.

\section{Menjelaskan Alat dan Bahan dalam Menulis Teks Prosedur}

Unit dua terdiri dari dua sub unit yaitu (1) menjelaskan alat dalam menulis teks prosedur dan (2) menjelaskan bahan dalam menulis teks prosedur Pada unit ini terdapat sedikit penjelasan tentang alat dan bahan yang terdapat dalam teks prosedur pada setiap sub unit, kemudian diikuti dengan latihan. Latihan pada sub unit pertama disajikan tiga gambar berbeda dan siswa diminta untuk menjelaskan alat yang terdapat dalam gambar-gambar tersebut. Pada sub unit kedua, siswa akan menjelaskan nama bahan, spesifikasi bahan, ukuran bahan, serta cara khusus penggunaan bahan yang terdapat pada gambar-gambar tersebut.

Unit dua dalam produk awal sebelum revisi adalah mengidentifikasi material dalam mengerjakan suatu pekerjaan/ aktivitas. Setelah revisi, judul unit dua berubah menjadi menjelaskan alat dan bahan dalam menulis teks prosedur. Penyajian materi dalam unit dua sebelum revisi dan sesudah revisi tidak jauh berbeda. Perbaikan dilakukan berdasarkan saran dari ahli (V1). Berdasarkan saran yang diberikan oleh ahli (V1) maka judul unit dua diubah dari mengidenifikasi material dalam mengerjakan suatu pekerjaan/aktivitas menjadi menjelaskan alat dan bahan dalam menulis teks prosedur. Selain itu, judul sub unit dalam bagian ini juga diubah. Alat dan bahan dalam sebuah teks prosedur dapat berupa daftar maupun paragraf.

Kearifan lokal Maluku yang dimunculkan dalam unit dua adalah cara membuat seruling bambu dan lampion. Pada unit ini disajikan gambar tentang prosedur atau cara membuat seruling bambu dan lampion karena dua benda tersebut merupakan salah satu jenis kearifan lokal Maluku.

\section{Memahami Langkah-Langkah dalam Mengerjakan Sesuatu}

Unit tiga dalam bahan ajar berisi langkah-langkah dalam mengerjakan sesuatu. Unit ini terdiri dari lima sub unit, yaitu (a) memahami urutan kegiatan dalam teks prosedur, (b) memahami kalimat perintah dalam teks prosedur, (c) memahami kalimat larangan dalam teks prosedur, (d) memahami kalimat pertanyaan dalam teks prosedur, (e) memahami kalimat pernyataan dalam teks prosedur. Pada pengembangan produk awal, unit ini terdiri dari lima sub unit, yakni (a) memahami langkah-langkah dalam mengerjakan suatu pekerjaan/aktivitas, (b) memahami perintah dalam mengerjakan suatu pekerjaan/aktivitas, (c) memahami larangan dalam mengerjakan suatu pekerjaan/ aktivitas, (d) memahami pertanyaan dalam mengerjakan suatu pekerjaan/ aktivitas, dan (e) memahami pernyataan dalam mengerjakan suatu pekerjaan/aktivitas. Setelah melewati uji ahli, maka judul sub unit pertama yang terdapat dalam unit ini diganti, sesuai saran dari ahli (V1). Berdasarkan saran yang diberikan oleh ahli (V1), maka judul setiap sub unit pada bagian ini diubah. Sub unit pertama dalam unit tiga diubah 
dari mengidentifikasi langkah-langkah dalam mengerjakan sesuatu menjadi urutan kegiatan dalam teks prosedur. Urutan kegiatan dalam teks prosedur berupa tahap persiapan yang berisi tujuan, tahap pelaksanaan yang berisi langkah-langkah, dan penutup yang berisi simpulan.

Pada unit tiga, jenis kearifan lokal Maluku yang ditampilkan adalah tarian dan kuliner. Kuliner yang disajikan dalam unit tiga berbeda dengan kuliner yang disajikan pada unit satu. Kuliner khas Maluku yang disajikan dalam unit tiga adalah cara membuat kue bagea dan kopi sibu-sibu. Di samping itu, tarian yang disajikan adalah tradisi puku sapu dan tarian sahu reku-reka. Dengan demikian tidak ada kesulitan dalam unit tiga, sebab semua jenis teks yang dimuat dalam unit tiga sering dijumpai dan dialami oleh siswa dalam kehidupan setiap hari.

\section{Memahami Struktur Teks Prosedur}

Unit empat dalam bahan ajar yang dikembangkan adalah memahami struktur teks prosedur. Pada bagian ini terdapat paragraf pengantar yang berisi penjelasan tentang struktur teks prosedur. Selain itu, disajikan contoh struktur teks prosedur dengan jelas, mulai dari bagian pembuka hingga penutup. Unit empat terdiri dari empat sub unit, yakni (a) menganalisis judul yang terdapat dalam teks prosedur, (b) menganalisis tujuan yang terdapat dalam teks prosedur, (c) mengidentifikasi material yang terdapat dalam teks prosedur, dan (d) mengidentifikasi tahapan/langkah yang terdapat dalam teks prosedur. Unit empat pada produk awal sebelum revisi adalah mengidentifikasi hierarki yang terdapat dalam teks prosedur dengan tiga sub unit yakni (a) mengidentifikasi struktur yang terdapat dalam teks prosedur, (b) mengidentifikasi kaidah kebahasaan yang terdapat dalam teks prosedur, dan (c) mengidentifikasi langkah-langkah dalam menyusun teks prosedur dengan tepat. Setelah revisi, unit empat dibagi menjadi dua unit, yakni memahami struktur teks prosedur dan identifikasi kaidah kebahasaan dan langkah-langkah dalam menulis teks prosedur sesuai saran yang diberikan dari ahli (V1).

Berdasarkan saran dari ahli (V1), maka unit empat dibagi menjadi dua unit. Unit empat tentang struktur teks prosedur dan unit lima tentang kaidah kebahasaan teks prosedur. Secara keseluruhan, dalam unit ini tidak ada perubahan sehingga penyajian materi yang terdapat dalam unit ini setelah maupun sebelum revisi tetap sama. Struktur teks prosedur terdiri dari judul, tujuan, alat dan bahan, serta tahapan/langkah. Teks prosedur dibangun oleh struktur yang membuatnya menjadi sebuah teks yang baik (Mandasari, Wella, Noveria, 2017).

Kearifan lokal yang disajikan dalam unit empat adalah cara membuat pisang goreng, kotak tissu, dan gantungan kunci dari kayu. Kearifan lokal yang disajikan dalam teks sangat jelas, prosedur kerja dijelaskan dengan rinci sehingga materi struktur teks prosedur dapat dipahami dengan baik. Penyajian struktur teks prosedur yang disajikan dalam contoh sangat terperinci dan mudah untuk dimengerti.

\section{Memahami Kaidah Kebahasaan serta Langkah-Langkah dalam Menyusun Teks Prosedur}

Unit lima terdiri dari dua sub unit, yakni (1) mengidentifikasi kaidah kebahasaan dalam teks prosedur dan (2) mengidentifikasi langkah-langkah dalam menulis teks prosedur. Sub unit pertama dalam unit lima yaitu identifikasi kaidah kebahasaan dalam teks prosedur. Pada sub unit ini diawali dengan penjelasan tentang kaidah kebahasaan teks prosedur dilengkapi dengan contoh dalam teks. Sub unit kedua dalam bagian ini terdiri dari tiga sub unit terkecil yakni, (a) menelaah teks prosedur secara utuh, (b) menyunting dan merevisi teks prosedur, dan (c) meringkas teks prosedur. Pada produk awal, bagian ini masuk dalam unit empat dengan judul mengidentifikasi hierarki yang terdapat dalam teks prosedur, setelah melalui uji ahli maka bagian ini masuk dalam unit lima dikarenakan pemecahan atau pembagian unit empat menjadi dua unit, yakni unit empat dan unit lima. Pembagian unit tersebut dilakukan berdasarkan saran dari ahli (V1).

Pada bagian ini, kaidah kebahasaan menduduki sub unit pertama karena kaidah kebahasaan sangat penting dalam menulis teks prosedur. Kaidah kebahasaan yang terdapat dalam sebuah teks prosedur antara lain konjungsi temporal, kata kerja imperatif, bilangan sebagai penanda urutan dan sebagainya. Setelah kaidah kebahasaan teks prosedur, sub unit berikut yaitu langkah-langkah dalam menulis teks prosedur, mulai dari menelaah, menyunting dan merevisi, serta meringkas teks prosedur.

Kearifan lokal Maluku yang terdapat dalam unit lima bermacam-macam, ada kuliner khas Maluku, cara membuat gelas bambu hingga cara membuat tangga bambu. Kuliner khas maluku yang disajikan dalam unit lima merupakan suatu prosedur tentang cara memasak yang sudah biasa dilihat, begitu pula dengan tangga bambu. Tiga jenis pekerjaan tersebut yang ditulis dalam teks merupakan sesuatu yang berhubungan dengan kehidupan siswa dan sering dijumpai di lingkungan. Tiga hal tersebut disajikan dalam bentuk teks prosedur dan dilengkapi dengan kaidah kebahasaan sehingga membantu siswa untuk memahami kaidah kebahasaan teks prosedur. 


\section{Menulis Teks Prosedur}

Unit terakhir dalam produk yang dikembangkan adalah menulis teks prosedur. Unit ini terdiri dari lima sub unit, yakni (a) menentukan topik teks prosedur, (b) merumuskan judul teks prosedur, (c) menulis bagian pembuka teks prosedur, (d) menulis bagian inti teks prosedur, dan (e) menulis bagian penutup teks prosedur. Sub unit pertama dalam menulis teks prosedur adalah menentukan topik teks prosedur. Bagian ini dijelaskan terlebih dahulu tentang bagaimana menentukan topik dalam menulis teks prosedur, kemudian diikuti dengan paparan materi tentang bagaimana mengumpulkan informasi yang berkaitan dengan topik yang akan ditulis ke dalam teks prosedur. Sub unit kedua dalam menulis teks prosedur adalah merumuskan judul. Pada bagian ini disajikan terlebih dahulu penjelasan tentang bagaimana merumuskan judul yang benar dan tepat. Sub unit ketiga dalam menulis teks prosedur adalah menulis bagian pembuka. Bagian ini berisi penjelasan tentang bagaimana menulis bagian pembuka teks prosedur. Sub unit keempat dalam menulis teks prosedur adalah menulis bagian inti. Sub unit terakhir dalam menulis teks prosedur adalah menulis bagian penutup.

Pada produk awal, bagian ini terdapat pada unit lima dengan judul panduan menulis teks prosedur. Unit ini kemudian dijadikan unit enam terkait unit empat dibagi menjadi dua unit, yakni unit empat dan unit lima sesuai dengan masukan atau saran dari ahli (V1). Berdasarkan dari ahli, kata panduan yang terdapat pada judul unit dihapus sehingga judul unit diubah dari panduan menulis teks prosedur menjadi menulis teks prosedur. Bentuk penyajian materi yang terdapat dalam unit ini setelah revisi tidak berbeda dengan penyajian materi sebelum revisi. Perbedaan hanya terlihat pada judul unit, dimana pada produk awal judul unit ini adalah panduan menulis teks prosedur, setelah melalui tahap uji ahli dan dilakukan revisi maka kata panduan dihapus sehingga judul unit ini setelah revisi adalah menulis teks prosedur. Bentuk penyajian materi tetap sama, sub unit dalam bagian ini juga tetap tanpa adanya penambahan maupun pengurangan sub unit. Hal penting dalam menulis teks prosedur adalah menentukan topik dan merumuskan judul. Judul yang terdapat dalam teks prosedur sedikit berbeda dengan judul yang terdapat dalam teks lain. Judul teks prosedur dapat berupa cara membuat sesuatu, cara memasak dan sebagainya.

Kearifan lokal yang disajikan dalam unit enam adalah cara membuat kuliner khas Maluku, salah satunya cara membuat Gatang Kenari yang disajikan pada sub unit pertama dalam unit enam. Kearifan lokal Maluku yang ditampilkan dalam unit enam tidak terlalu banyak dan rinci karena pada unit ini, siswa dilatih untuk menulis teks prosedur dengan bertahap. Proses penulisan teks prosedur mulai dari menentukan topik hingga pada menulis bagian penutup teks prosedur. Oleh karena itu, kearifan lokal yang disajikan sesuai dengan porsi tiap-tiap sub unit.

Setiap sub unit yang terdapat dalam bahan ajar ini, secara keseluruhan dilengkapi dengan latihan-latihan yang dapat mengasah kemampuan berpikir siswa untuk mengenal teks prosedur lebih dalam. Teks-teks yang disajikan dalam bahan ajar ini berkaitan dengan lingkungan kehidupan siswa sehingga akan memudahkan siswa dalam menulis, sebab apa yang dilihat, dialami, dan dilakukan dapat dituangkan dalam sebuah teks prosedur. Dengan demikian, siswa merasa terbantu karena bahan ajar ini digunakan sebagai sumber belajar.

\section{SIMPULAN}

Berdasarkan analisis penelitian Pengembangan Bahan Ajar Menulis Teks Prosedur Bermuatan Kearifan Lokal Maluku untuk Siswa SMP Klas VIII dapat disimpulkan bahwa produk yang dikembangkan memiliki enam unit. Pertama, mengenal teks prosedur dengan enam subu nit, yakni (a) membaca dan memahami teks prosedur, (b) merumuskan definisi teks prosedur, (c) menyimpulkan tujuan dan jenis teks prosedur, (d) menyimpulkan ciri teks prosedur, (e) menyimpulkan struktur teks prosedur, dan (f) menyimpulkan kaidah kebahasaan teks prosedur. Kedua, menjelaskan alat dan bahan dalam menulis teks prosedur terdiri dari dua sub unit, yakni (a) menjelaskan alat dalam menulis teks prosedur, dan (b) menjelaskan bahan dalam menulis teks prosedur. Ketiga, memahami langkah-langkah dalam mengerjakan sesuatu, terdiri dari lima sub unit, yakni (a) memahami urutan kegiatan dalam teks prosedur, (b) memahami kalimat perintah dalam teks prosedur, (c) memahami kalimat larangan dalam teks proesdur, (d) memahami kalimat pertanyaan dalam teks prosedur, (e) memahami kalimat pernyataan dalam teks prosedur. Keempat, memahami struktur teks prosedur terdiri dari empat sub unit, yakni (a) menganalisis judul yang terdapat dalam teks prosedur, (b) menganalisis tujuan yang terdapat dalam teks prosedur, (c) mengidentifikasi material yang terdapat dalam teks prosedur, dan (d) mengidentifikasi tahapan/langkah yang terdapat dalam teks prosedur. Kelima, mengidentifikasi kaidah kebahasaan dan langkah-langkah dalam menyusun teks prosedur terdiri dari dua sub unit, yakni (a) mengidentifikasi kaidah kebahasaan dalam teks prosedur, (b) mengidentifikasi langkah-langkah dalam menulis teks prosedur. Keenam, menulis teks prosedur terdiri dari lima sub unit, yakni (a) menentukan topik teks prosedur, (b) merumuskan judul teks prosedur, (c) menulis bagian pembuka teks prosedur, (d) menulis bagian inti teks prosedur, dan (e) menulis bagian penutup teks prosedur.

Kearifan lokal Maluku yang terdapat dalam bahan ajar yang dikembangkan bermacam-macam. Teks yang disajikan dalam setiap unit sangat berkaitan dan berhubungan dengan lingkungan keseharian siswa. Produk yang dikembangkan telah melalui tahap uji kelayakan dan uji coba lapangan sehingga bahan ajar menulis teks prosedur bermuatan kearifan lokal Maluku layak untuk diimplementasikan. Hal ini dapat dilihat pada hasil uji beda antara nilai pretes dan postes yang memiliki perbedaaan yang signifikan, yaitu nilai pretes adalah 46, 56, dan nilai postes 86,08 . Dengan demikian, bahan ajar menulis teks prosedur bermuatan kearifan lokal Maluku dapat digunakan sebagai sumber belajar untuk materi teks prosedur. 
Bahan ajar ini dapat dimanfaatkan oleh guru bahasa Indonesia maupun guru muatan lokal sebagai acuan dalam mengajarkan materi teks prosedur serta kearifan lokal Maluku. Bahan ajar ini juga dapat dijadikan sebagai rujukan dalam menghasilkan latihan-latihan yang bervariasi. Produk ini dapat digunakan oleh seluruh kelas VII SMP di Maluku karena produk ini dikembangkan sesuai dengan tingkat berpikir siswa dengan bermuatan lokan Maluku.

Terdapat dua saran yang ditujukan untuk peneliti lanjutan, yaitu (1) pemilihan jenis teks. Bahan ajar dikembangkan untuk pembelajaran menulis tes prosedur, sebaiknya peneliti lanjutan mengembangkan jenis teks lain yang terdapat dalam kurikulum; (2) kearifan lokal dalam bahan ajar. Kearifan lokal yang diintegrasikan ke dalam bahan ajar menulis teks prosedur tidak mencakup keseluruhan. Oleh karena itu, peneliti lanjutan dapat mengembangkan produk berdasarkan kearifan lokal atau budaya lain yang belum digunakan dalam bahan ajar ini.

\section{DAFTAR RUJUKAN}

Anggraini, S., Rusminto, Nurlaksana, E., \& Agustina, E. S. (2015). Pembelajaran Memahami Teks Prosedur Kompleks pada Siswa Kelas X. Jurnal Kata (Bahasa, Sastra, dan Pembelajarannya), 2(4), 1-8.

Aprilianti, N. F. F., \& Sugiarto, B. (2014). Penerapan Model Pembelajaran Induktif untuk Melatih Keterampilan Metakognitif Siswa pada Materi Larutan Penyangga. Unesa Journal of Chemical Education, 3(2), 246-254.

Asriati, N. (2012). Mengembangkan Karakter Peserta Didik Berbasis Kearifan Lokal Melalui Pembelajaran di Sekolah. Jurnal Pendidikan Sosiaologi dan Humaniora, 3(2).

Astuti, Y. W., \& Mustadi, A. (2014). Pengaruh Penggunaan Media Film Animasi terhadap Keterampilan Menulis Karangan Narasi Siswa Kelas V SD. Jurnal Prima Edukasia, 2(2), 250-262. https://doi.org/10.21831/jpe.v2i2.2723

Dewi, P. C., Hudiyono, Y., \& Mulawarman, W. G. (2018). Pengembangan Bahan Ajar Menulis Teks Prosedur Kompleks dengan Model Pembelajaran Discovery Learning menggunakan Media Audio Visual (Video) di Kelas XI SMA Negeri 1 Samarinda. Diglosia: Jurnal Kajian Bahasa, Sastra, dan Pengajarannya, 1(2), 101-112. https://doi.org/10.30872/diglosia.v1i2.pp101-112.

Durukan, E. (2011). Effects of Cooperative Integrated Reading and Composition (CIRC) Technique on Reading-Writing Skills. Educational Research and Reviews.

Fajarini, U. (2014). Peranan Kearifan Lokal dalam Pendidikan Karakter. SOSIO DIDAKTIKA: Social Science Education Journal, 1(2), 123-130. https://doi.org/10.15408/sd.v1i2.1225

Jones, V. S., Holland, A. J. A., \& Oldmeadow, W. (2008). Inductive Teaching Method - An Alternate Method for Small Group Learning. Medical Teacher. https://doi.org/10.1080/01421590802259274

Kellogg, R. T. (2008). Training Writing Skills: A Cognitive Developmental Perspective. Journal of Writing Research. https://doi.org/10.17239/jowr-2008.01.01.1

Kellogg, R. T., \& Raulerson, B. A. (2007). Improving the Writing Skills of College Students. Psychonomic Bulletin and Review. https://doi.org/10.3758/BF03194058

Kristanti, K. W., \& Sriasih, S. A. P., \& Astika, I. M. (2015). Penerapan Metode Demonstrasi Guru Bahasa Indonesia dalam Pembelajaran Teks Prosedur pada Siswa Kelas VIII A1 SMP Negeri 3 Sawan. Jurnal Pendidikan Bahasa dan Sastra Indonesia Undiksa, 3(1), 1-12.

Lestari, D. W., Herdiantina., \& Sudrajat, R. T. (2018). Pembelajaran Menulis Teks Prosedur dengan menggunakan Metode CTL (Contextual Teaching and Learning) pada Siswa Kelas X MAN Cimahi. Parole: Jurnal Pendidikan Bahasa dan Satra Indonesia, 1(5), 815-820.

Mandasari, W. A., Atmazaki., \& Noveria, E. (2017). Pengaruh Model Project Based Learning Berbantuan Media Gambar terhadap Keterampilan Menulis Teks Prosedur. Jurnal Pendidikan Bahasa dan Sastra Indonesia, 6(2), 401-408.

Meliono, I. (2011). Understanding The Nusantara Thought and Local Wisdom as an Aspect of the Indonesian Education. TAWARIKH: International Journal for Historical Studies, 2(2), 221-234.

Mungmachon, M. R. (2012). Knowledge and Local Wisdom: Community Treasure. International Journal of Humanities and Social Science, 2, 174-181.

Nadlir, M. (2016). Urgensi Pembelajaran Berbasis Kearifan Lokal. Jurnal Pendidikan Agama Islam, 2(2), $300-330$.

Oktaria, D., Andayani, \& Saddhono, K. (2017). Penguasaan Kalimat Efektif sebagai Kunci Peningkatan Keterampilan Menulis Eksposisi (The Mastery of Effective Sentences as the Key to Improve Exposition Writing Skill). Metalingua, 15(2), 165177.

Owon, R. A. S. (2017). Pengembangan Bahan Ajar Menulis Berbagai Jenis Teks Bertema Kearifan Lokal Sikka bagi Siswa SMP. JINoP (Jurnal Inovasi Pembelajaran), 3(1), 528-541. https://doi.org/10.22219/jinop.v3i1.4318

Pattinama, M. J. (2009). Pengentasan Kemiskinan dengan Kearifan Lokal (Studi Kasus di Pulau Baru-Maluku dan Surade-Jawa Barat). Maraka - Jurnal Sosial Humaniora, 13(1), 1-12.

Persada, N. P. R., Mangunjaya, F. M., Tobing, I. S. (2018). Sasi sebagai Budaya Konservasi Sumber Daya Alam di Kepulauan Maluku. Ilmu dan Budaya, 41(59), 6869-6900. 
Pornpimon, C., Wallapha, A., \& Prayuth, C. (2014). Strategy Challenges the Local Wisdom Applications Sustainability in Schools. Procedia - Social and Behavioral Sciences. https://doi.org/10.1016/j.sbspro.2014.01.1210

Pratama, F., Pratiwi, Y., \& Andajani, K. (2016). Pengembangan Bahan Ajar Menulis Teks Eksposisi Bermuatan Cinta Lingkungan dengan Strategi Pemodelan untuk Siswa Kelas VII SMP. Jurnal Pendidikan: Teori, Penelitian, dan Pengembangan, 1(3), 448-462.

Qalby, U. N. M. R. J. Y. (2017). Efektivitas Model Pembelajaran Kooperatif Tipe Teams Games Tournaments dalam Keterampilan Menulis Bahasa Jerman Siswa Kelas XII IPA SMA Negeri 1 Bontonompo Kabupaten Gowa. Jurnal Penelitian Pendidikan INSANI, 20(1), 67-72.

Rao, Z. (2007). Training in Brainstorming and Developing Writing Skills. ELT Journal, 61, 100-106. https://doi.org/10.1093/elt/ccm002

Saputro, E., Widodo, M., \& Rusminto, N. E. (2014). Pengembangan Bahan Ajar Menulis Berbasis Nilai-Nilai Kearifan Lokal. Jurnal J-Simbol (Bahasa, Sastra, dan Pembelajarannya), 2 (1), 1-15.

Selasih, N. N., \& Sudarsana, I. K. (2018). Education Based on Ethnopedagogy in Maintaining and Conserving the Local Wisdom: A Literature Study. Jurnal Ilmiah Peuradeun, 6(2), 292-306. https://doi.org/10.26811/peuradeun.v6i2.219

Sugiyono, P. D. (2016). Metode Penelitian Kuantitatif, Kualitatif, dan R \& D. Bandung: Alfabeta.

Sugiyo, R., \& Purwastuti, L. A. (2017). Local Wisdom-Based Character Education Model in Elementary School in Bantul Yogyakarta Indonesia. Sino-US English Teaching, 14(5), 299-308. https://doi.org/10.17265/1539-8072/2017.05.003

Sumaryati, E., \& Sumarno, U. (2013). Pendekatan Induktif-Deduktif Disertai Strategi Think-Pair-Square-Share untuk Meningkatkan Kemampuan Pemahaman dan Berpikir Kritis serta Disposisi Matematis Siswa SMA. Infinity Journal, 2(1), 26-42. https://doi.org/10.22460/infinity.v2i1.22

Suyitno, I. (2013). Pengembangan Pendidikan Karakter dan Budaya Bangsa Berwawasan Kearifan Lokal. Jurnal Pendidikan Karakter, 2(1), 1-13.

Wanti, N., Juariah., Farlina, E., Kariadinata, R., \& Sugilar, H. (2017). Pembelajaran Induktif pada Kemampuan Penalaran Matematis dan Self-Regulated Learning Siswa. Jurnal Analisa, 3(1), 56-69. https://doi.org/10.15575/ja.v3i1.1497

Wijayanti, W., \& Zulaeha, I. R. (2015). Pengembangan Bahan Ajar Interaktif Kompetensi Memproduksi Teks Prosedur Kompleksyang Bermuatan Kesantunan bagi Peserta Didik Kelas X SMA/MA. Seloka - Jurnal Pendidikan Bahasa dan Sastra Indonesia, 4(2), 94-101.

Wikanengsih. (2013). Model Pembelajaran Neurolinguistic Programming Berorientasi Karakter bagi Peningkatan Kemampuan Menulis Siswa SMP. Semantik, 19(2), 177-186. 